\title{
Spatial distribution of the giant scallop Placopecten magellanicus in unharvested beds in the Baie des Chaleurs, Québec
}

\author{
Kevin D. E. Stokesbury*, John H. Himmelman \\ Département de Biologie and GIROQ (Groupe Interuniversitaire de Recherches Océanographiques du Québec), \\ Université Laval, Québec, Canada G1K 7P4
}

\begin{abstract}
Large and small scale distributions of the giant scallop Placopecten magellanicus were determined in 2 scallop beds near Port Daniel in the Baie des Chaleurs, eastern Canada. Large scale $(\mathrm{km})$ distribution was strongly associated with substrates of gravel or gravel mixed with sand. Within each bed, small scale $(\mathrm{cm})$ distribution was contagious corresponding to a negative binomial distribution. Morisita's index confirmed the contagious spatial distribution and showed that clump size was approximately $1.13 \mathrm{~m}^{2}$ in one bed and $4.50 \mathrm{~m}^{2}$ in the other. The majority of scallops in both beds were within clumps. Small scale aggregation was not related to substrate type. Mature and immature scallops were significantly associated in the less densely populated bed but not in the more densely populated bed. This suggests that immature scallops moved nearer to adult scallops when densities were low. Both sexes were present in $79 \%$ of clumps of adult scallops. In both beds the sex ratio was 1:1 and scallops did not appear to seek out members of the opposite sex. In the 2 beds 91 and $75 \%$ of nearest neighbor scallop pairs were $100 \mathrm{~cm}$ or closer to each other. The short distance between scallops within clumps, the high proportion of clumps with both sexes present, and an average of 3 scallops per clump suggest high fertilization success within clumps. We suggest that the small scale aggregation of scallops is an adaptation to increase fertilization success, and if this is true, disturbance of these aggregations may decrease reproductive success.
\end{abstract}

\section{INTRODUCTION}

The distribution of scallops including Placopecten magellanicus (Gmelin, 1791) is generally described at 3 different spatial scales: (1) geographic areas known as 'grounds', (2) 'beds' on the scale of kilometres, and (3) 'patches' on the scale of 10 's to 100 's of metres (Brand 1991). Tidal and residual currents have an effect on larval distribution and the location of aggregations at the geographic scale (Sinclair et al. 1985, Tremblay \& Sinclair 1988). Currents also affect scallop distribution by influencing swimming patterns (Posgay 1981, Melvin et al. 1985, Thouzeau et al. 1991a). Thouzeau et al. (1991a, b) showed that scallop density on Georges Bank (NW Atlantic) is clearly related to

\footnotetext{
- Present address: Department of Fisheries and Oceans, Biological Station, St. Andrews, New Brunswick, Canada EOG $2 \times 0$
}

sediment type and that highest densities occur on gravel. They suggested that scallops are randomly distributed, on the scale of metres, within any given substrate type. MacDonald \& Bajdik (1992) also observed a small scale random distribution of scallops near Colinet, Newfoundland, and suggested that this random pattern was caused by scallops attempting to space themselves out to prevent competition for resources. Scallop larvae may be gregarious at settlement so that spat might occur in specific sites (Brand 1991). Hydrozoans and bryozoans appear to be strongly preferred substrates for larval scallop settlement (Brand et al. 1980, M. Harvey \& E. Bourget pers. comm.). Finally, scallop distribution may be determined by interspecific interactions. Langton \& Robinson (1990) showed that the distribution of adult scallops in the Gulf of Maine is negatively correlated to the distribution of the cerianthid anemone Cerianthus borealis which feeds on scallop larvae. In reviewing 
the literature on scallop predators, Brand (1991) concluded that although predation on adult scallops reduces density it is not usually sufficient to control local distribution. However, some predators can evoke a strong escape response in scallops (Brand 1991, Manuel \& Dadswell 1991) which affects the dispersion of seeded juvenile scallops (Barbeau et al. 1992).

Placopecten magellanicus is a gonochoristic species which spawns large quantities of gametes into the water column. Spawning occurs from August to October and varies between different geographical regions although it is generally highly synchronous within any given part of a population (Naidu 1970 , MacDonald \& Thompson 1985, 1986, Barber et al. 1988, Dupaul et al. 1989, Parsons et al. 1992). Synchronous spawning may enhance fertilization success.

Many population studies of scallops have been based on dredged samples which provide estimates of population density used in stock assessments but are of little value for studies of small scale distribution (Caddy 1968, 1970, Brand 1991). More accurate sampling is possible using SCUBA and submersibles equipped with still photography and video cameras (Caddy 1970, Langton \& Robinson 1990). Although the submersible enables surveying of large areas in deep water, it is less efficient than SCUBA diving (Caddy 1970) and it is difficult to collect samples. Sampling using SCUBA remains the most accurate method for examining the distribution of scallops but this is limited to shallow water. Previous estimates have been based on quadrats or corridors of up to $1 \mathrm{~m}$ in width (Vahl 1981, Orensanz 1986, Gwyther \& McShane 1988, Berkman 1991, Tettelbach 1991). One exception is the

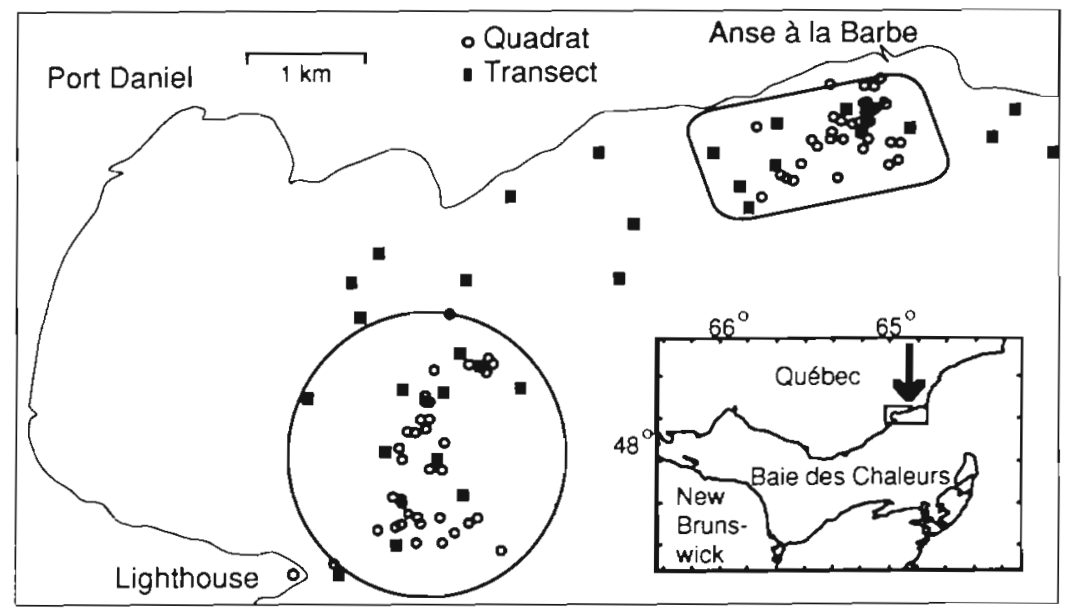

Fig. 1. Location of the transect and quadrat surveys in the Port Daniel Bay area of the Baie des Chaleurs. Circled areas represent the Lighthouse and Anse à la Barbe scallop beds. Inset: Location of the Baie des Chaleurs in relation to Québec and New Brunswick, the Gulf of St. Lawrence, Canada study by Caddy (1968) where scallops were sampled in $21.2 \mathrm{~m}^{2}$ corrals. Recently, MacDonald \& Bajdik (1992) analyzed scallop distribution within a $15 \times 15 \mathrm{~m}$ grid in 2 scallop beds along the Newfoundland coast using both SCUBA and still photography. None of these previous studies analyzed the exact spatial distribution of scallops within observation areas using nearest neighbor distance methods.

In this study we examined the distribution of Placopecten magellanicus within 2 unharvested scallop beds in the Baie des Chaleurs, Gulf of St. Lawrence, eastern Canada, using SCUBA diving techniques. We first tested the hypothesis that scallops have a contagious distribution on large $(\mathrm{km})$ and small $(\mathrm{cm})$ scales. After finding this to be true, we went on to examine clump size (area), clump density (scallops per clump), and clump distribution. We analyzed the relationships of scallops, including distances and sex ratios of ncarest neighbor scallop pairs at the scale of centimetres, and considered their determining mechanisms.

\section{MATERIAL AND METHODS}

The 2 scallop beds studied were in the Port Daniel region on the Québec shore of the Baie des Chaleurs (Fig. 1) $\left(48^{\circ} 48^{\prime} 00^{\prime \prime} \mathrm{N}, 64^{\circ} 58^{\prime} 00^{\prime \prime} \mathrm{W}\right)$. The larger bed, the Lighthouse bed, was oval in shape and covered ca $5.0 \mathrm{~km}^{2}$ area, at a depth of 20 to $24 \mathrm{~m}$, whereas the smaller rectangular Anse à la Barbe bed covered ca $2.3 \mathrm{~km}^{2}$ area, at a depth of 16 to $23 \mathrm{~m}$. The $2.5 \mathrm{~km}$ of substrate between these beds was mainly bedrock and supported a low scallop density. The tidal currents in the Port Daniel region were semidiurnal and had a maximum range of $1.7 \mathrm{~m}$ during this study.

The 2 scallop beds were chosen because, according to local fisherman, they have not been fished during the last $20 \mathrm{yr}$ as their density is below that required for commercial fishing (Boulanger \& Myre 1971); in addition scallops in this area are not collected by sport divers. No traces of dredging of the beds were noted.

Large $(\mathrm{km})$ scale scallop distributions in the Port Daniel area were examined using thirty $50 \mathrm{~m}$ transects from 3 June and 5 July 1991 (Fig. 1). Transect lines were placed along the bottom from a boat and their position determined using compass and Loran $C$ bearings. Each of 2 divers made observations in a $1 \mathrm{~m}$ wide strip along the 
transect so that a total area of $100 \mathrm{~m}^{2}$ was examined They recorded the position and size of each scallop encountered and noted the different types of substrates along the transect. The substrate categories were sand $(<1 \mathrm{~mm})$, gravel $(0.1$ to $10 \mathrm{~cm})$, rock $(10$ to $100 \mathrm{~cm})$, boulders (>100 cm) and bedrock.

To examine small scale scallop distributions 37 graduated ( $\mathrm{cm}$ ) quadrats, each $3 \times 3 \mathrm{~m}$, were placed within each bed from 12 to 26 July 1991. These were positioned over the bed from a boat using a rough compass bearing. After placing each quadrat, its exact position was determined by compass and Loran $\mathrm{C}$ bearings (Fig. 1). The quadrats were allowed to fall to the bottom from the boat to ensure that they were placed randomly. On several occasions the quadrat was observed as it fell onto the bottom and no scallops were noted to swim as it settled. This was possibly because the quadrat was made of light plastic and settled onto the bottom slowly. Divers recorded the position of each scallop to the nearest centimetre. When the nearest neighbor of a scallop within the quadrat was outside the quadrat but within a maximum of $1 \mathrm{~m}$ from the quadrat edge, that neighbor's position was also recorded. This $1 \mathrm{~m}$ boundary strip is necessary to prevent biased nearest neighbor measurements for scallops near the edge of the quadrat (Krebs 1989). The substrate type within each quadrat was also recorded. Care was taken to prevent scallops from swimming; when a scallop appeared to be preparing to swim, it was prevented from doing so by a diver touching it Each scallop was collected and its shell height (mm) and sex determined. Sex was identified by gonad color (Davidson \& Worms 1989), except for immature scallops where the gonads were undeveloped and beige in color.

Large $(\mathrm{km})$ and small $(\mathrm{cm})$ scale distributions of scallops were compared to both Poisson (random) and negative binomial (contagious) distributions. The arithmetic mean of the number of scallops per sample is the only parameter required to calculate the Poisson distribution (Elliott 1971). The negative binomial distribution uses this arithmetic mean and the exponent $k$, which is related to the spatial distribution on the bottom and is estimated by using the method of maximum likelihood (Elliott 1971). Only scallops within and touching the edge of the quadrat were used in distribution estimates. Expected values derived from these models were grouped according to Cochran's rule, which states that $<20 \%$ of the expected frequencies should have a value $<5$. Agreement between the observed and expected values was evaluated using chisquare tests at the 5 and $1 \%$ levels of significance (Elliott 1971, Sokal \& Rohlf 1981). When the number of degrees of freedom was equal to 1, Yates' correction was used in the chi-square test (Spiegel 1981).
We also used Morisita's index of dispersion (I) to examine scallop distribution. Morisita's index gives a detailed analysis of the pattern of dispersion. It is independent of the mean number of scallops per quadrat and of the sum of the number of scallops per quadrat. However, it is strongly affected by the number of quadrats (Elliott 1971, Langton \& Robinson 1990). Thus it is preferable to use the same number of quadrats when comparing 2 populations as we did in our study. An index of 1 is obtained for a random distribution whereas a greater value indicates a contagious distribution (Elliott 1971). We calculated a standardized Morisita's index to verify our distribution estimates. The standardized Morisita's index is independent of population density and sample size and therefore it is presently the best measurement of dispersion (Krebs 1989). Morisita's index is also strongly influenced by quadrat size (Elliott 1971, Langton \& Robinson 1990). If the size of the quadrat is much larger or smaller than the average clump size then the dispersion of the population is apparently random and non-randomness is not detected. If several different sample sizes are used and the mean to variance ratio is always unity, then a random population distribution is strongly indicated (Elliott 1971). To evaluate this effect, starting in a given corner, we sequentially reduced the $9 \mathrm{~m}^{2}$ quadrats by half 4 times. Thus, we obtained quadrats of $4,5,2.25$, 1.13 and $0.56 \mathrm{~m}^{2}$, respectively. These results were verified by repeating the process but finishing in the opposite corner of the $9 \mathrm{~m}^{2}$ quadrat. For each quadrat size, we calculated Morisita's index and tested for departures from randomness (Elliott 1971).

The scale of clumping within a population was estimated by dividing the Morisita's index for one quadrat size by the Morisita's index for the next largest quadrat size $\left(I_{x} / I_{x+1}\right)$ and plotting this ratio against the larger quadrat size of $I_{x+1}$. A peak occurs when quadrat size and clump size are approximately equal (Elliott 1971). The number of clumps per quadrat was then calculated based on the estimate of clump size for each bed, and the frequency of clumps compared to a Poisson distribution. Morisita's index of dispersion was also calculated for clump distribution to estimate departures from randomness.

Within a quadrat and its $1 \mathrm{~m}$ boundary strip, each scallop's position (cm) was plotted and its size and sex determined. The nearest neighbor analysis technique was then used to determine nearest neighbor ratios between male and female scallops and between mature and immature scallops. Proportions of sexes and of immatures and matures within each clump were also determined. These various ratios were compared to expected frequencies using chi-square tests (Spiegel 1981).

Chi-square tests were used to determine whether 


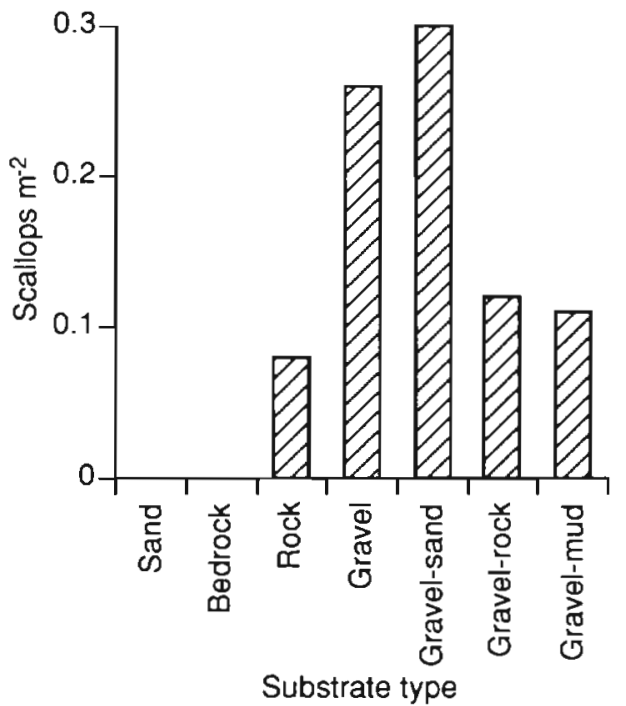

Fig. 2. Placopecten magellanicus. Association between substrate type and scallop density (ind. $\mathrm{m}^{-2}$ ) in the Port Daniel Bay area, based on samples collected from thirty $100 \mathrm{~m}^{2}$ transects

the association of scallops with substrates differed from a random association, using the data from the $50 \mathrm{~m}$ transects, and to compare the substrates of the 2 scallop beds with the quadrat data. The mean densities from the quadrat samples of the 2 scallop beds were compared using a Student $t$ distribution.
A 1 -way ANOVA was applied to the quadrat data to compare scallop densities to substrates within the scallop beds.

\section{RESULTS}

The transect survey showed that the large scale $(\mathrm{km})$ distribution of Placopecten magellanicus in the Port Daniel area was contagious $\left(x^{2}=2.31, \mathrm{df}=1, \mathrm{p}>0.05\right.$; agreement with a negative binomial distribution) and strongly associated with substrate type, $\left(\chi^{2}=269.09\right.$, $\mathrm{df}=6, \mathrm{p}<0.01)$. The highest $P$. magellanicus densities $\left(0.30 \mathrm{~m}^{-2}\right)$ were on gravel and gravel mixed with other materials (Fig. 2)

The density of Placopecten magellanicus, estimated from the quadrat survey, was significantly greater in the Lighthouse bed $\left(0.57 \mathrm{~m}^{-2}\right)$ than in the Anse à la Barbe bed $\left(0.34 \mathrm{~m}^{-2}\right)(t=2.29, \mathrm{p}<0.05)$. In both beds, scallop distribution was significantly different from a random (Poisson) distribution and similar to a negative binomial distribution (Table 1), indicating that the scallops were clumped. Morisita's index and Morisita's standardized index also showed a significant agreement with a contagious distribution pattern (Table 2). However, as quadrat area decreased the scallop distribution became random for both beds.

The clump size of scallops in the Lighthouse bed was $1.13 \mathrm{~m}^{2}$ compared to $4.50 \mathrm{~m}^{2}$ for the Anse à la Barbe bed (Fig. 3). The mean number of scallops per clump

Table 1 Placopecten magellanicus. Chi-square analysis comparing observed scallop frequencies to Poisson and negative binomial distributions using data from 37 quadrats collected in both the Lighthouse and Anse à la Barbe beds in the Port Daniel Bay area. Departure from expected frequencies are significant at $\cdots p<0.01$

\begin{tabular}{|c|c|c|c|c|c|}
\hline \multicolumn{3}{|c|}{ Poisson series } & \multicolumn{3}{|c|}{ Negative binomial } \\
\hline $\begin{array}{c}\text { Scallops } \\
\text { per quadrat }\end{array}$ & $\begin{array}{l}\text { Observed } \\
\text { Erequency }\end{array}$ & $\begin{array}{l}\text { Expected } \\
\text { frequency }\end{array}$ & $\begin{array}{c}\text { Scallops } \\
\text { per quadrat }\end{array}$ & $\begin{array}{l}\text { Observed } \\
\text { frequency }\end{array}$ & $\begin{array}{l}\text { Expected } \\
\text { frequency }\end{array}$ \\
\hline \multicolumn{6}{|c|}{ Lighthouse bed } \\
\hline $0-3$ & 15 & 9.12 & $0-1$ & 8 & 6.39 \\
\hline 4 & 2 & 6.30 & $2-3$ & 7 & 8.98 \\
\hline 5 & 3 & 6.48 & $4-5$ & 5 & 7.67 \\
\hline 6 & 4 & 5.54 & $6-7-8$ & 10 & 7.43 \\
\hline 7 & 2 & 4.07 & $9(+)$ & 7 & 5.37 \\
\hline $8(+)$ & 11 & 5.46 & & & \\
\hline$x^{2}$ & & $15.70^{\circ}$ & & & 3.16 \\
\hline \multicolumn{6}{|c|}{ Mean $=5.14$, variance $=13.56, \mathrm{df}=4$ for Poisson; $\mathrm{df}=2, k=2.33$ for negative binomial distribution } \\
\hline \multicolumn{6}{|c|}{ Anse à la Barbe bed } \\
\hline $0-1$ & 9 & 6.79 & 0 & 4 & 4.77 \\
\hline 2 & 11 & 7.99 & 1 & 5 & 6.78 \\
\hline 3 & 7 & 8.28 & 2 & 11 & 6.66 \\
\hline 4 & 4 & 6.43 & 3 & 7 & 5.56 \\
\hline $5-6$ & 1 & 6.07 & $4-5$ & 5 & 7.29 \\
\hline $71+1$ & 5 & 1.45 & $6(+)$ & 5 & 5.74 \\
\hline$x^{2}$ & & $15.90 \cdots$ & & & 4.61 \\
\hline
\end{tabular}


Table 2. Placopecten magellanicus. Morisita's index of dispersion for scallops within the Lighthouse and Anse à la Barbe beds. The data are from 37 quadrats collected in both beds. In the first reduction, the $9 \mathrm{~m}^{2}$ quadrat was reduced by half 4 times. This process was repeated in the second reduction but to the opposite corner of the quadrat. Departure from randomness is significant when $I\left(\sum x-1\right)+\left(n-\sum x\right)$ is outside the $\chi^{2}$ value for $n-1$ degrees of freedom or a value equal to or greater than 0.5 or equal to or less than -0.5 for the standardized Morisita's index; " $p<0.05, \cdots p<0.01$

\begin{tabular}{|c|c|c|c|c|c|}
\hline \multirow[t]{2}{*}{ Scallop bed } & \multicolumn{5}{|c|}{ Quadrat size $\left(\mathrm{m}^{2}\right)$} \\
\hline & 9 & 4.5 & 2.25 & 1.13 & 0.56 \\
\hline \multicolumn{6}{|l|}{ Lighthouse } \\
\hline Morisita's index & 1.31 & 1.26 & 1.07 & 1.45 & 1.85 \\
\hline Significance & $95.1 \cdots$ & $64.0^{\cdots}$ & 39.90 & $48.9^{\cdots}$ & $48.7^{\cdots}$ \\
\hline Standardized & $0.50^{\circ}$ & $0.50^{\circ}$ & 0.09 & $0.50^{\circ}$ & 0.31 \\
\hline Second reduction & 1.31 & 1.31 & 1.13 & 0.80 & 2.06 \\
\hline Significance & $95.1 \cdots$ & $67.8^{*}$ & 41.96 & 31.50 & 44.40 \\
\hline Standardized & $0.50^{\circ}$ & $0.50^{\circ}$ & 0.15 & 0.48 & 0.21 \\
\hline \multicolumn{6}{|l|}{ Anse à la Barbe } \\
\hline Morisita's index & 1.49 & 1.41 & 1.75 & 1.35 & 0.00 \\
\hline Significance & $91.8^{*}$ & $59.5 \%$ & $52.6^{\cdots}$ & 39.50 & \\
\hline Standardized & $0.50^{\circ}$ & $0.50^{\circ}$ & 0.40 & 0.48 & -0.12 \\
\hline Second reduction & 1.49 & 1.44 & 1.58 & 1.30 & 0.82 \\
\hline Significance & $91.9^{*}$ & $60.5^{\cdots}$ & $51.1^{\circ}$ & 41.40 & 34.40 \\
\hline Standardized & $0.50^{\circ}$ & $0.50^{\circ}$ & 0.39 & 0.13 & -0.04 \\
\hline
\end{tabular}

Table 3. Placopecten magellanicus. Chi-square analysis comparing scallop clump distribution to a Poisson distribution and checked with Morisita's index of dispersion. Data were from 37 quadrats collected in both the Lighthouse and Anse à la Barbe beds. Departure from randomness was calculated by $x^{2}$ test; distribution was found to be random in both beds

\begin{tabular}{|c|c|c|c|c|c|}
\hline \multirow[b]{2}{*}{$\begin{array}{l}\text { Clumps per } \\
\text { quadrat }\end{array}$} & \multicolumn{2}{|c|}{ Lighthouse bed } & \multicolumn{3}{|c|}{ Anse à la Barbe bed } \\
\hline & $\begin{array}{l}\text { Observed } \\
\text { frequency }\end{array}$ & $\begin{array}{l}\text { Expected } \\
\text { frequency }\end{array}$ & $\begin{array}{l}\text { Clumps per } \\
\text { quadrat }\end{array}$ & $\begin{array}{l}\text { Observed } \\
\text { frequency }\end{array}$ & $\begin{array}{l}\text { Expected } \\
\text { frequency }\end{array}$ \\
\hline 0 & 12 & 9.30 & 0 & 11 & 14.00 \\
\hline 1 & 7 & 12.90 & 1 & 17 & 13.60 \\
\hline 2 & 11 & 8.90 & $2-3$ & 9 & 8.70 \\
\hline $3-4$ & 7 & 5.50 & $x^{2}$ & & 1.07 \\
\hline$x^{2}$ & & 4.39 & & & \\
\hline \multicolumn{3}{|c|}{$\begin{array}{l}\text { Clump size } 1.13 \mathrm{~m}^{2} ; \mathrm{df}=2 \\
\text { Morisita's index } 0.80\end{array}$} & \multicolumn{2}{|c|}{$\begin{array}{l}\text { Clump size } 4.50 \mathrm{~m}^{2} ; \mathrm{df}=1 \\
\text { Morisita's index } 0.65\end{array}$} & \\
\hline
\end{tabular}

Table 4. Placopecten magellanicus. Chi-square analysis comparing the nearest neighbor associations among scallop pairs of difterent sexes and stages of maturity in both the Lighthouse and Anse à la Barbe beds. Departure from randomness was calculated by $x^{2}$ test $_{i}^{*} p<0.05$

\begin{tabular}{|c|c|c|c|c|c|}
\hline Ratio & $\begin{array}{l}\text { Observed } \\
\text { frequency }\end{array}$ & $\begin{array}{l}\text { Expected } \\
\text { frequency }\end{array}$ & Ratio & $\begin{array}{l}\text { Observed } \\
\text { frequency }\end{array}$ & $\begin{array}{l}\text { Expected } \\
\text { frequency }\end{array}$ \\
\hline \multicolumn{6}{|c|}{ Lighthouse bed } \\
\hline Male-Male & 21 & 16.3 & Mature-Mature & 65 & 63.8 \\
\hline Male-Female & 32 & 32.5 & Mature-Immature & 73 & 69.5 \\
\hline Female-Female & 12 & 16.3 & Immature-Immature & 15 & 18.9 \\
\hline$x^{2}$ & & 2.49 & $x^{2}$ & & 1.00 \\
\hline \multicolumn{6}{|c|}{ Anse à la Barbe bed } \\
\hline Male-Male & 16 & 14.0 & Mature-Mature & 56 & 66.7 \\
\hline Male-Female & 29 & 28.0 & Mature-Immature & 43 & 29.4 \\
\hline Female-Female & 11 & 14.0 & $x^{2}$ & & $7.40^{\circ}$ \\
\hline$x^{2}$ & & 1.00 & & & \\
\hline
\end{tabular}




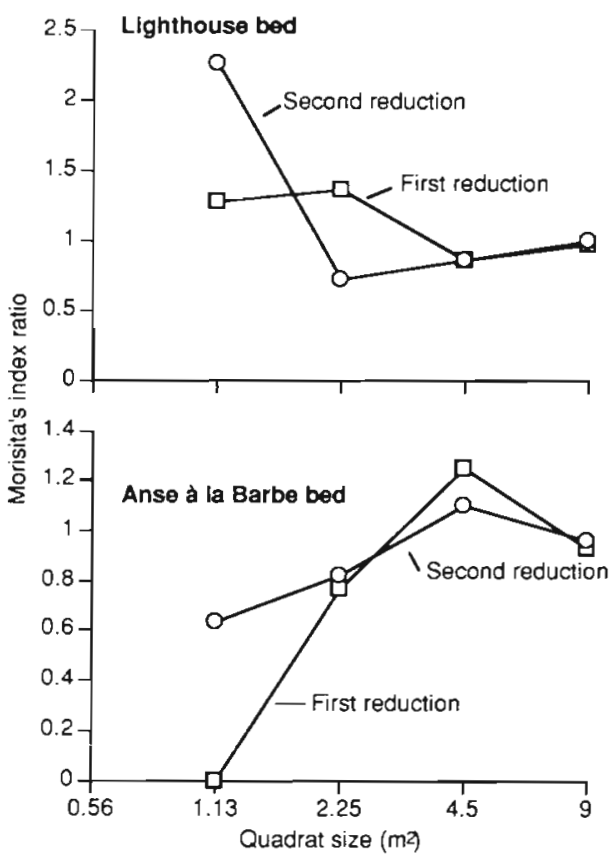

Fig. 3. Placopecten magellanicus. Comparison of Morisita's index ratio $\left(I_{x} / I_{x+1}\right)$ to quadrat size of $I_{x+1}$ for both the Lighthouse and Anse à la Barbe scallop beds. Peaks in the lines occur when quadrat size and clump size are approximately equal. In the first reduction, the $9 \mathrm{~m}^{2}$ quadrat was reduced by half 4 times. This process was repeated in the second reduction but to the opposite corner of the quadrat

was similar for both beds $[\bar{X}=2.9$ ( $S D=2.1)$ scallops in the Lighthouse bed and $\bar{x}=3.1(\mathrm{SD}=2.1)$ scallops in the Anse à la Barbe bed] but the maximum number of scallops per clump was 5 in the Lighthouse bed compared to 9 in the Anse à la Barbe bed. In the Lighthouse bed, clumps covered $17 \%$ of the area sampled $\left(57.4 / 333 \mathrm{~m}^{2}\right)$ and $78 \%(150 / 193$ scallops) of the scallops were within clumps. In the Anse à la Barbe bed, clumps covered $49 \%$ of the area sampled $\left(162 / 333 \mathrm{~m}^{2}\right)$ and $87 \%$ of the sampled scallops were within clumps (110/126 scallops). The distribution of scallop clumps within both beds was random (Table 3 ); however, this may have been because the quadrat size was not substantially larger than clump size.

The sex ratios of adult scallops in both the
Lighthouse (69 males / 54 females; $\chi^{2}=1.5$, df $=1$, $p>0.05$ ) and Anse à la Barbe (51 males / 51 females) beds were not significantly different from $1: 1$. The sexes were associated randomly so that there was an equal chance of a scallop's nearest neighbor being a male or a female (Table 4). Both sexes were present in $84 \%$ of the clumps of mature scallops in the Lighthouse bed and $74 \%$ of the clumps in the Anse à la Barbe bed (Table 5).

The ratio of mature to immature scallops $(<49 \mathrm{~mm})$ was 2:1 (123 matures/65 immatures) in the Lighthouse bed and 4:1 (102 matures / 25 immatures) in the Anse à la Barbe bed. In the Lighthouse bed, mature and immature scallops were associated randomly (Table 4). In contrast, mature and immature scallops were significantly associated in the Anse à la Barbe bed (Table 4). In the Lighthouse and Anse à la Barbe bed, $39 \%$ and $25 \%$ of the total clumps, respectively, had either mature scallops of a single sex and one or more immature scallops or only immature scallops (Table 5).

In the Lighthouse bed 91.6 of the nearest neighbor scallop pairs were $<100 \mathrm{~cm}$ apart while in the Anse à la Barbe beds $90.9 \%$ of the nearest neighbor scallop pairs were $140 \mathrm{~cm}$ or closer (Fig. 4). In the Lighthouse bed, mature nearest neighbor scallop pairs were equally distributed over a distance ranging from 0 to $100 \mathrm{~cm}$. However, the majority of immature-immature and mature-immature nearest neighbor scallop pairs were within $60 \mathrm{~cm}$ of each other. In the Anse à la Barbe bed, no mature nearest neighbor scallop pairs were closer than $20 \mathrm{~cm}$ to each other, but as distance increased the frequency of mature nearest neighbor scallop pairs increased until a distance of $100 \mathrm{~cm}$ was reached. After $100 \mathrm{~cm}$ the frequency of mature nearest neighbor scallop pairs decreased sharply. The frequency of mature-immature nearest neighbor scallop pairs decreased after a distance of $120 \mathrm{~cm}$ in the Anse à la Barbe bed. In both beds, $9 \%$ of all scallops inside the quadrats may have had a nearest neighbor beyond the $1 \mathrm{~m}$ boundary strip, therefore these estimates may be slightly skewed.

Within the 2 scallop beds, the frequencies of the various types of substrates were similar $\left(\chi^{2}=8.25, \mathrm{df}=9\right.$, $p>0.05$ ) and gravel was the predominant substrate

Table 5. Placopecten magellanicus. Proportion of mature scallop clumps with both sexes present or with a single sex present, and clumps made up either of immature scallops and only of one sex of mature scallops or only immature scallops, in both the Lighthouse and Anse à la Barbe beds

\begin{tabular}{|c|c|c|c|c|}
\hline \multirow[t]{2}{*}{ Scallop bed } & \multirow{2}{*}{$\begin{array}{c}\text { Clump size } \\
\left(m^{2}\right)\end{array}$} & \multicolumn{2}{|c|}{ Mature clumps } & \multirow[t]{2}{*}{ Immature clumps } \\
\hline & & Both sexus & Single sex & \\
\hline Lighthouse & 1.13 & $26(84 \%)$ & $5(16 \%)$ & $20(39 \%)$ \\
\hline Anse à la Barbe & 4.50 & $20(74 \%)$ & $7(26 \%)$ & $9(25 \%)$ \\
\hline
\end{tabular}


in both. Only 1 quadrat in the Lighthouse bed and 5 quadrats in the Anse à la Barbe bed did not contain gravel. Scallop density was not significantly related to substrate type in either bed $(p=0.09$ in the Lighthouse bed, $p=0.41$ in the Anse à la Barbe bed: ANOVAl, although the highest densities $(0.88$ scallops $\mathrm{m}^{-2}$ at the Lighthouse and 0.56 scallops $\mathrm{m}^{-2}$ at the Anse à la Barbe bed) were observed on gravel-sand substrate.

\section{DISCUSSION}

The large scale $(\mathrm{km})$ distribution of Placopecten magellanicus was contagious in Port Daniel Bay. This corroborates previous findings on $P$. magellanicus (Caddy 1968, 1970, Caddy \& Carter 1984, Langton \& Robinson 1990, Thouzeau et al. 1991a) and other scallop species (see review by Brand 1991). In the Port Daniel region, scallop aggregation at the large scale $(\mathrm{km})$ was strongly associated with substrate type, the highest densities being on sand-gravel and gravel substrates. High densities are also strongly associated with these substrates throughout the range of $P$. magellanicus (Caddy 1970, Langton \& Robinson 1990, Brand 1991, Thouzeau et al. 1991a).

In our study, small scale $(\mathrm{cm})$ aggregations occurred in both scallop beds but were greater in the Lighthouse bed, where the higher scallop density 10.57 scallops $\mathrm{m}^{-2}$ ) was found. Lighthouse bed scallop clumps were smaller, covered less total area, and had a greater total number of scallops compared to clumps in the Anse à la Barbe bed. In the Lighthouse bed, immature and mature scallops were randomly distributed, but in the Anse à la Barbe bed they were significantly associated, even though immatures were less common in this bed. This could indicate that immature scallops moved closer to mature scallops when mean scallop densities were low

MacDonald \& Bajdik (1992) found a small scale contagious distribution for large scallops (>110 $\mathrm{mm}$ shell height) in their low density $\left(0.19\right.$ scallops $\left.\mathrm{m}^{-2}\right)$ scallop bed and a random distribution in their high density (0.86 scallops $\mathrm{m}^{-2}$ ) scallop bed. When they included scallops $<110 \mathrm{~mm}$ in shell height, distributions in both scallop beds became random. MacDonald \& Bajdik's (1992) results are the opposite of our findings. They suggested that at low densities scallops form local aggregations if food supply is not limited but they did not speculate on the reason for this behavior. They also stated that at high densities scallop distribution be-
Lighthouse bed

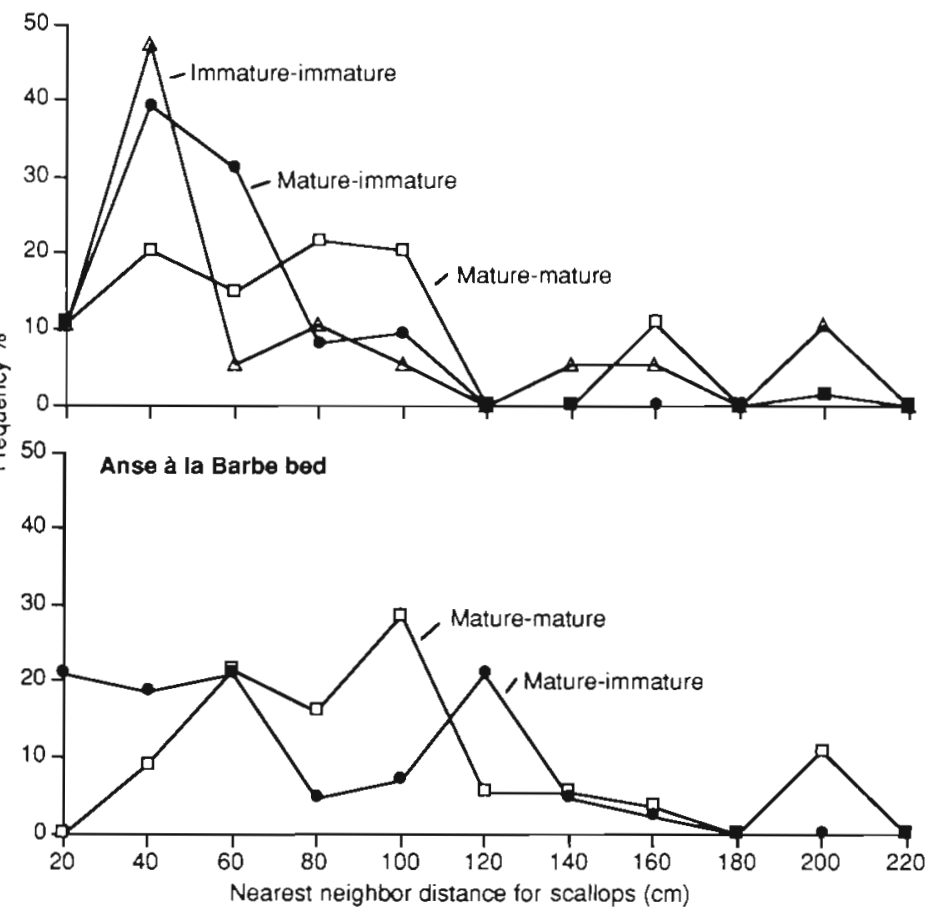

ig. 4. Placopecten magellanicus. Frequencies of distances for maturemature, mature-immature, and immature-immature nearest neighbors callop pairs in both the Lighthouse and Anse à la Barbe scallop beds; distances were clumped in groups at $20 \mathrm{~cm}$ intervals

came random due to scallops attempting to prevent competition for food by spacing themselves. We found that small scale aggregation was not related to substrate type, which was similar in both our scallop beds. Also, the light tidal currents over this homogeneous substrate would not form eddies and would probably not contribute to scallop clumping. Further, small scale aggregation was probably not influenced by food limitation in the Lighthouse bed, where $11 \%$ of nearest neighbor scallop pairs were $20 \mathrm{~cm}$ or closer and $91 \%$ of nearest neighbor scallop pairs were $100 \mathrm{~cm}$ or closer. Food availability may have affected clump size in the Anse à la Barbe bed, where no mature nearest neighbor scallop pairs were closer than $20 \mathrm{~cm}$ to each other and clump area was large, but not to the extent that it inhibited aggregative behavior.

Small scale aggregation of scallops could be an adaptation to enhance fertilization success. Both sexes were present in $79 \%$ of adult scallop clumps in our 2 scallop beds. Nevertheless, scallops did not appear to seek out members of the opposite sex as there was an equal probability of the nearest neighbor being male or female. If the number of scallops per clump is 3, and this was the average in the Port Daniel region, there is a $75 \%$ chance that both sexes will be present in adult clumps (assuming that the sexes are randomly distrib- 
uted). If 4 scallops make up a clump, the probability of both sexes being present in that clump increases to $87.5 \%$. However, if the clump area increases and the number of individuals per clump remains the same, the probability of gametes from different individuals encountering each other would decrease. Fertilization success in the sea urchin Strongylocentrotus droebachensis is 60 to $95 \%$ when males and females are within $20 \mathrm{~cm}$ of each other but the success rate drops to $<15 \%$ when the distance between individuals is $>20$ cm (Pennington 1985). Denny \& Shibata (1989) suggested that in marine organisms, the low effectiveness of external fertilization can lead to self-compatibility in hermaphrodites, internal fertilization, synchronous spawning and behavior leading to the aggregation of spawning adults. Further, group size, degree of aggregation, position within spawning group, and water flow, all of which affect sperm concentration and sperm-egg contact, have a strong effect on fertilization success of marine echinoderms (Levitan 1991, Levitan et al. 1991, 1992). These studies show that sperm concentration is rapidly diluted within metres of its source so that the concentration is insufficient for successful fertilization if distance between spawning individuals

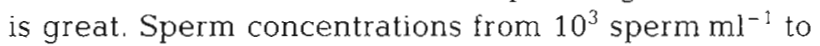
$4.7 \times 10^{7}$ sperm $\mathrm{ml}^{-1}$ are required to obtain high fertilization success in echinoderms (Pennington 1985, Levitan et al. 1991). However, fertilization success can be extremely high if population densities are large and spawning is synchronous (Sewell \& Levitan 1992). Minchin (1989) suggested that directional movement in 2 scallop species, Pecten maximus and Mihuzopecten (Patinopecten) yessoensis, occurs to enhance synchronized spawning. Laboratory experiments on Placopecten magellanicus suggest similar concentrations, $5 \times 10^{4}$ to $5 \times 10^{6}$ sperm ml-1, were required for successful fertilization (J. Bonardelli unpubl. data). The majority of scallops in both the beds we examined were in clumps. The majority of nearest neighbor scallop pairs in both the Lighthouse (91\%) and Anse à la Barbe $(75 \%)$ beds were within $100 \mathrm{~cm}$ of each other. The short distance between nearest neighbor scallop pairs within clumps, an average of 3 scallops per clump, and the high proportion of clumps with both sexes present suggest a higher fertilization success within clumps and lower fertilization success outside of clumps.

To determine the size of clumps, it is necessary to sample a population using a variety of quadrat sizes (Elliott 1971) Most previous studies examining spatial cistribution of Placopecten magellanicus used either $1 \mathrm{~m}^{2}$ quadrats or $1 \mathrm{~m}$ wide sampling corridors and the exact position of scallops was not noted. Beds of scallops at the scale of 0.9 to $1.9 \mathrm{~km}^{2}$ have been reported (Caddy 1970, Langton \& Robinson 1990), which are on the same scale as the large scale distribution of scallops in Port Daniel Bay. Our data on the exact position of scallops permitted resampling using different sized quadrats and nearest neighbor analysis, which showed that aggregation also occurred on the order of centimetres. If sampling is conducted using a quadrat size similar to the clump size, the variance among samples will be maximized and this will prevent identification of aggregations (Green 1979). Many of the previous studies would not have detected the small scale clumps we describe because of the similarity of the quadrat size to clump size $\left(1 \mathrm{~m}^{2}\right.$ quadrats or $1 \mathrm{~m}$ wide corridors), because scallops within a sample were collected as a single unit, and because of the uniformity of the sampling unit. Clump distribution appears to be random, which suggests that patches do not exist on the scale of 10's or 100's of metres in the Port Daniel beds. However, our sampling method does not allow a rigorous statistical analysis of contagious patterns on this scale.

Scallop dredging may have negative effects on scallop populations because it increases mortality (directly and indirectly) and stimulates aggregation of predators (Caddy 1970, 1973). Further, Langton \& Robinson (1990) showed that dredging for scallops has a severe impact on natural faunal association. Thouzeau et al. (1991a) determined that scallops are randomly distributed within each sediment type $\left(\mathrm{m}^{2}\right.$ scale) on Georges Bank where fishing pressure is heavy. We suggest that aggregation, on the scale of centimetres, in scallop beds may be an adaptation to increase fertilization success. If this is true, it is likely that disturbing such aggregations, by dredging or other activities, would decrease reproductive success.

Acknowledgements. We thank S. Bernier, N. Dubé and J. Lessard for their assistance in the field. Dr M. Claereboudt provided statistical advice and help with computer programing. J. Parsons, M. Stokesbury and Drs E. Holmes, M. Dadswell and S. Robinson reviewed this manuscript and provided many helpful comments. Funds for this project were provided by OPEN, and NSERC grants to J.H.H.; the senior author was supported by a Bourse d'Etudes for graduate students from Laval University and by OPEN.

\section{LITERATURE CITED}

Barbeau, M. A., Scheibling, R. E., Hatcher, B. G., Taylor, L. H., Hennigar, A. W. (1992). Predation of juvenile sea scallops (Placopecten magellanicus) by sea stars (Asterias spp.) and crabs (Cancer irroratus) in lab and field experiments. In: Arai, M. N., Aral, H. P., Renaud, J.-M. (eds.) Bull. Can. Soc. Zool. 23: 133

Barber, B. J., Getchell, R., Shumway, S., Schick, D. (1988). Reduced fecundity in a defep-water population of the giant scallop Placopecten magellanicus in the Gulf of Maine, USA. Mar. Ecol. Prog. Ser. 42: 207-21.2 
Berkman, P. A. (1991). Spatial distribution of an unexploited nearshore Antartic scallop population. In: Shumway, S. E., Sandifer, P. A. (eds.) An international compendium of scallop biology and culture. The World Aquaculture Society, Baton Rouge, p. 176-179

Boulanger, J.-M., Myre, G. (1971). Prospection des bancs de pètoncles de la Gaspèsie et de la basse Côte-Nord. Rapport Annuel 1971 Ministère de l'Industrie et du Commerce, Direction génerale des Pêches Maritimes, Québec, p. 100-108

Brand, A. R. (1991). Scallop ecology: distributions and behaviour. In: Shumway, S. E. (ed.) Scallops: biology, ecology and aquaculture. Elsevier, New York, p. 517-584

Brand, A. R., Paul, J. D., Hoogesteger, J. N. (1980). Spat settlement of the scallops Chlamys opercularis (L.) and Pecten maximus (L.) on artificial collectors. J. mar. biol. Ass. U.K. $60: 379-390$

Caddy, J. F. (1968). Underwater observations on scallop (Placopecten magellanicus) behaviour and drag efficiency. J. Fish. Res. Bd Can. 25: 2123-2141

Caddy, J. F. (1970). A method of surveying scallop populations from a submersible. J. Fish. Res. Bd Can. 27: 535-549

Caddy, J. F. (1973). Underwater observations on tracks of dredges and trawls and some effects of dredging on a scallop ground. J. Fish. Res. Bd Can. 30: 173-180

Caddy, J. F., Carter, J. A. (1984). Macro-epifauna of the lower Bay of Fundy - observations from a submersible and analysis of faunal adjacencies. Can. Tech. Rep. Fish. Aquat. Sci. 1254: 1-35

Davidson, L. A., Worms, J. (1989). Stages of gonad development in the sea scallop Placopecten magellanicus (Gmelin) based on both macroscopic and microscopic observation of the gametogenic cycle. Can. Tech. Rep. Fish. Aquat. Sci. 1686: 1-20

Denny, M. W. Shibata, M. F. (1989). Consequences of surfzone turbulence for settlement and external fertilization. Am. Nat. 134: 859-889

Dupaul, W. D., Kirkley, J. E., Schmitzer, A. C. (1989). Evidence of a semiannual reproductive cycle for the sea scallop, Placopecten magellanicus (Gmelin, 1791), in the mid-Atlantic region. J. Shellfish Res. 8: 173-178

Elliott, J. M. (1971). Statistical analysis of benthic invertebrates. Freshwat. Biol. Ass. Sci. Publ. No. 25: 1-142

Green, R. H. (1979). Sampling design and statistical methods for environmental biologists. John Wiley \& Sons, New York

Gwyther, D., McShane, P. E. (1988). Growth rate and natural mortality of the scallop Pecten alba Tate in Port Phillip Bay, Australia and evidence for changes in growth rate after a 20-year period. Fish. Res. 6: 347-361

Krebs, C. J. (1989). Ecological methodology. Harper \& Row, New York

Langton, R. W., Robinson, W. R. (1990). Faunal associations on scallop grounds in the western Gulf of Maine. J. exp. mar. Biol. Ecol. 144: 157-171

Levitan, D. R. (1991). Influence of body size and population density on fertilization success and reproductive output in a free-spawning invertebrate. Biol. Bull. 181: 261-268

Levitan, D. R., Sewell, M. A., Chia, F.-S. (1991). Kinetics of fertilization in the sea urchin Strongylocentrotus franciscanus: interaction of gamete dilution, age, and contact time. Biol. Bull 181: 371-378

Levitan, D. R., Sewell, M. A., Chia, F.-S. (1992). How distribution and abundance influence fertilization success in the sea urchin Strongylocentrotus franciscanus. Ecology 73 : $248-254$

MacDonald, B. A., Bajdik, C. D. (1992). Orientation and distri- bution of individual Placopecten magellanicus (Gmelin) in two natural populations with differing production. Can. J. Fish. Aquat. Sci. 49: 2086-2092

MacDonald, B. A., Thompson, R. J (1985). Influence of temperature and food availability on the ecological energetics of the giant scallop Placopecten magellanicus. II. Reproductive output and total production. Mar. Ecol. Prog. Ser. 25: 295-303

MacDonald, B. A., Thompson, R. J. (1986). Influence of temperature and food availability on the ecological energetics of the giant scallop Placopecten magellanicus. III. Physiological ecology, the gametogenetic cycle and scope for growth. Mar. Biol 93: 37-48

Manuel, J. L., Dadswell, M. J. (1991). Swimming behavior of juvenile giant scallop, Placopecten magellanicus, in relation to size and temperature. Can. J. Zool 69: 2250-2254

Melvin, G. D., Dadswell, M. J., Chandler, R. A. (1985). Movement of scallops Placopecten magellanicus (Gmelin, 1791) (Mollusca: Pectinidae) on Georges Bank. Canadian Atlantic Fisheries Scientific Advisory Committee, Fisheries and Oceans, Dartmouth, 85/30

Minchin, D. (1989). Up-slope movements in the scallop Pecten maximus. J. mollusc. Stud. 55: 423-425

Naidu, K. S. (1970). Reproduction and breeding cycle of the giant scallop Placopecten magellanicus (Gmelin) in Port au Port Bay, Newfoundland. Can. J. Zool. 48: $1003-1012$

Orensanz, J. M. (1986). Size, environment and density: the regulation of a scallop stock and its management implications. In: Jamieson, G. S., Bourne, N. (eds.) North Pacific workshop on stock assessment and management of invertebrates. Can. Spec. Publ. Fish. Aquat. Sci. 92: 195-227

Parsons, G. J., Robinson, S. M. C., Chandler, R. A., Davidson, L. A., Lanteigne, M., Dadswell, M. J. (1992). Intra-annual and long-term patterns in the reproductive cycle of giant scallop Placopecten magellanicus (Bivalvia: Pectinidae) from Passamaquoddy Bay, New Brunswick, Canada. Mar. Ecol. Prog. Ser. 80: 203-214

Pennington, J. T (1985). The ecology of fertilization of echinoid eggs: the consequences of sperm dilution, adult aggregation, and synchronous spawning. Biol. Bull. 169: $417-430$

Posgay, J. A. (1981). Movement of tagged sea scallops on Georges Bank. Mar. Fish. Rev. 43: 19-25

Sewell, M. A., Levitan, D. R. (1992). Fertilization success during a natural spawning of the dendrochirote sea cucumber Cucumaria miniata. Bull. mar. Sci. 51(2): 161-166

Sinclair, M., Mohn, R. K, Robert, R. K., Roddick, D. L. (1985). Considerations for the effective management of Atlantic scallops. Can. Tech. Rep. Fish. Aquat. Sci. 1382: 1-113

Sokal, R. R., Rohlf, F. J. (1981). Biometry. Freeman, San Francisco

Spiegel, M. R. (1981). Theory and problems of statistics. Schaum's outline series. McGraw-Hill Book Company, New York

Tettelbach, S. T (1991). Seasonal changes in a population of northern bay scallops, Argopecten irradians irradians (Lamarck, 1819). In: Shumway, S. E., Sandifer, P. A. (eds.) An international compendium of scallop biology and culture. The World Aquaculture Society, Baton Rouge, p. $164-175$

Thouzeau, G., Robert, G., Smith, S. J. (1991a). Spatial variability in distribution and growth of juvenile and adult sea scallops Placopecten magellanicus (Gmelin) on eastern Georges Bank (Northwest Atlantic). Mar Ecol. Prog. Ser. 74: $205-218$ 
Thouzeau, G., Robert, G., Ugarte, R. (1991b). Faunal assemblages of benthic megainvertebrates inhibiting sea scallop grounds from eastern Georges Bank, in relation to environmental factors. Mar. Ecol. Prog. Ser. 74:61-82

Tremblay, M. J., Sinclair, M. M. (1988). The vertical and horizontal distribution of sea scallop (Placopecten magellani-

This article was submitted to the editor cus) larvae in the Bay of Fundy in 1984 and 1985. J. Northw. Atl. Fish. Sci. 8: 43-53

Vahl, O. (1981). Energy transformations by the Iceland scallop. Chlamys islandica (O. F. Müller), from 70 $\mathrm{N}$. II. The population budget. J. exp. mar. Biol. Ecol. 53: $297-303$

Manuscript first received: December 22, 1992

Revised version accepted: February 23, 1993 